\title{
REKAYASA MIKROSFER ZEOLIT SEBAGAI PENYANGGA KATALIS FCC DENGAN BAHAN BAKU MINERAL KAOLIN
}

\author{
Tjokorde Walmiki Samadhi*, Febrinaldo Eka Nugraha \\ Program Studi Teknik Kimia, FTI, Institut Teknologi Bandung \\ Jalan Ganeca 10 Bandung 40132 \\ Email: twsamadhi@che.itb.ac.id
}

\begin{abstract}
Abstrak
Kajian ini merupakan evaluasi awal kelayakan pembuatan katalis fluid catalytic cracking (FCC) dari kaolin Indonesia. Kaolin Belitung mula-mula diolah menjadi mikrosfer kaolin dengan pengeringan sembur. Mikrosfer kemudian dipilah menjadi dua bagian, satu bagian dikenai perlakuan kalsinasi rendah (pada temperatur 700-850 ${ }^{\circ} \mathrm{C}$ ) dan sisanya dikenai kalsinasi tinggi $\left(1000{ }^{\circ} \mathrm{C}\right)$. Metakaolin hasil kalsinasi pada kedua tingkat temperatur ini dicampurkan, dan direaksikan dengan larutan $\mathrm{NaOH}$ secara hidrotermal pada temperatur 100-110 ${ }^{\circ} \mathrm{C}$. Reaksi hidrotermal selama 18-24 jam membentuk fasa faujasit pada permukaan mikrosfer kaolin, yang diidentifikasi dengan metode difraksi sinar-X dan dengan pengamatan morfologi menggunakan metode SEM. Karakterisasi tekstural produk dengan adsorpsi nitrogen menghasilkan luas permukaan spesifik sebesar 10,5-142,1 $\mathrm{m}^{2} / \mathrm{g}$, volume pori $0,007-0,097 \mathrm{~cm}^{3} / \mathrm{g}$, serta median diameter pori $13,1-15,6 \AA$ A Selain diameter pori, sifatsifat tekstural ini masih kurang dibandingkan dengan katalis-katalis FCC yang dipaparkan di literatur. Pengolahan data percobaan dengan metode ANOVA mengidentifikasi periode waktu kalsinasi rendah serta interaksi antara temperatur kalsinasi rendah dan periode reaksi hidrotermal sebagai faktor-faktor yang menentukan luas permukaan spesifik. Berdasarkan analisis ini, luas permukaan dapat ditingkatkan dengan memilih waktu kalsinasi rendah yang relatif singkat (sekitar 2 jam), dan mengatur temperatur kalsinasi dan periode waktu reaksi hidrotermal secara serempak pada tingkat tinggi (masing-masing sekitar $850^{\circ} \mathrm{C}$ dan 24 jam).
\end{abstract}

Kata kunci: mikrosfer kaolin, Belitung, metakaolin, faujasit, FCC

\begin{abstract}
DEVELOPMENT OF ZEOLITE AS FCC CATALYST SUPPORT USING KAOLIN AS A RAW MATERIAL. This study is a preliminary evaluation of the feasibility of manufacturing fluid catalytic cracking (FCC) catalysts using Indonesian kaolins. A Belitung kaolin sample was spray-dried to form kaolin microspheres, and divided into two parts. One part is processed by low calcination (at $700-850^{\circ} \mathrm{C}$ ) and the other by high calcination $\left(1000^{\circ} \mathrm{C}\right)$. Metakaolins produced by these treatments were mixed, and reacted with concentrated $\mathrm{NaOH}$ solution hydrothermally at $100-110{ }^{\circ} \mathrm{C}$. A reaction period of $18-24$ hours produced faujasite phase growth on the microsphere surface, as identified by X-ray diffraction and SEM morphology characterization. Measurement of textural properties by nitrogen adsorption produced a specific surface area of $10.5-142.1 \mathrm{~m}^{2} / \mathrm{g}$, pore volume of $0.007-0.097 \mathrm{~cm}^{3} / \mathrm{g}$, and median pore size of 13.1-15.6 $\AA$. Except for the pore diameter, these properties were still substantially lower than FCC catalysts described in the literature. ANOVA data analysis identified calcination time and the interaction between calcination temperature and hydrothermal reaction period as significant effects. Based on this analysis, the specific surface area may be increased by setting the low calcination period at low level (approximately 2 hours) while simultaneously setting calcination temperature and hydrothermal reaction period at high levels (approximately $850{ }^{\circ} \mathrm{C}$ and 24 hours, respectively).
\end{abstract}

Keywords: kaolin microsphere, Belitung, metakaolin, faujasite, FCC

*penulis korespondensi 


\section{PENDAHULUAN}

Lempung merupakan istilah umum bagi keluarga mineral aluminosilikat yang sangat penting secara komersial. Di Indonesia, jenis mineral lempung yang tersedia dalam cadangan relatif besar adalah kaolin. Cadangan-cadangan besar kaolin di Indonesia terdapat di kepulauan Bangka-Belitung dan Kalimantan Barat (Murray, 2007). Salah satu aplikasi kaolin yang menonjol dalam industri proses adalah sebagai bahan katalis perengkahan dalam proses perengkahan katalis terfluidakan (fluid catalytic cracking atau FCC) (Sadeghbeigi, 2000). Proses FCC memiliki tingkat kepentingan yang semakin tinggi dalam teknologi kilang minyak bumi modern, karena kemampuannya untuk mengolah minyak mentah berkualitas rendah menjadi komponen-komponen bahan bakar berkualitas tinggi. Seperti yang telah umum diketahui, salah satu kecenderungan yang sangat penting dalam pasaran minyak mentah dunia adalah pergeseran ketersediaan minyak mentah ke arah minyak-minyak yang berkualitas rendah, yang memiliki berat jenis /viskositas sangat tinggi, dan dengan kandungan logam-logam berat serta sulfur yang kian tinggi pula.

Formulasi katalis FCC konvensional terdiri dari zeolit, matriks, bahan pengisi (filler), serta bahan pengikat (binder). Zeolit, yang memiliki distribusi ukuran pori yang terekayasa dengan teliti, berfungsi sebagai fasa aktif yang melaksanakan perengkahan molekul-molekul hidrokarbon dalam alur umpan. Pentingnya peranan zeolit dalam katalisis proses FCC tercermin dari profil konsumsi global katalis zeolit, dimana sekitar 95\% dari seluruh volume perdagangan katalis zeolit adalah untuk mendukung proses FCC (Yilmaz dkk., 2012).

Matriks dalam katalis FCC didefinisikan sebagai komponen-komponen non-zeolit, yang dapat berperan aktif dalam perengkahan maupun tidak. Bahan pengisi umumnya berupa kaolin, dan berfungsi membatasi aktivitas serta memberikan integritas fisik katalis. Bahan pengikat berfungsi merekatkan semua komponen katalis tersebut menjadi agregat yang memiliki kekuatan mekanik memadai. Dalam teknik preparasi katalis FCC konvensional, yang juga dikenal dengan teknik inkorporasi, seluruh komponen katalis di atas dicampurkan menjadi suspensi dan dibentuk menjadi produk akhir katalis melalui proses pengeringan sembur (spray drying) (Sadeghbeigi, 2000).

Salah satu teknik alternatif dalam preparasi katalis FCC dikenal sebagai teknik in-situ. Dalam teknik ini, kaolin dan bahan pengikat terlebih dahulu disuspensikan dan dibentuk menjadi mikrosfer melalui pengeringan sembur. Setelah itu, fasa aktif zeolit ditumbuhkan secara in-situ di permukaan mikrosfer kaolin dalam kondisi hidrotermal dengan kehadiran alkali. Produk katalis yang dihasilkan dengan teknik ini secara inheren merupakan bahan komposit, yang tersusun dari fasa zeolit dan non-zeolit (Brown dkk., 1985). Keunggulan utama yang ditawarkan oleh katalis FCC yang dibuat dengan teknik in-situ adalah kekuatan mekanik yang lebih baik pada kadar zeolit tinggi. Dalam hal ini, teknik inkorporasi terkendala oleh penurunan kekuatan mekanik yang selalu terjadi pada kadar zeolit relatif tinggi (Brown dkk., 1985).

Kajian ini merupakan kajian awal pembuatan katalis FCC melalui proses zeolitisasi in-situ kaolin yang berasal dari dalam negeri. Ketersediaan metode-metode zeolitisasi parsial di literatur umum meniadakan keharusan untuk mengembangkan metode sendiri dari nol. Sebagai penelitian awal, kajian ini diarahkan pada evaluasi awal kelayakan teknis penggunaan kaolin Indonesia sebagai bahan baku katalis FCC. Evaluasi ini didasarkan pada sifat-sifat fisik dan morfologi produk katalis mikrosfer yang dibandingkan dengan karakteristik katalis komersial atau katalis yang dipaparkan dalam literatur. Sebagai kajian awal, kajian ini belum menjangkau pengukuran aktivitas katalitik produk katalis FCC yang diperoleh.

\section{METODE}

Bahan baku utama yang digunakan dalam kajian ini adalah mineral kaolin yang ditambang di daerah pulau Belitung. Pengadaan sampel kaolin ini dilakukan melalui jasa Balai Besar Keramik Kemenperin RI di Bandung. Secara visual, kaolin ini dicirikan dengan morfologi yang homogen, berwarna putih sedikit kecoklatan, serta ukuran partikel yang secara kualitatif halus. Karakterisasi sampel kaolin ini mencakup analisis komposisi oksida dengan metode analisis kimia basah (wet chemical analysis) di Program Studi Teknik Pertambangan ITB, identifikasi fasa-fasa kristalin dengan difraksi 
sinar-X di Program Studi Teknik Pertambangan ITB, serta karakterisasi morfologi dengan teknik Scanning Electron Miscroscopy (SEM) di laboratorium Pusat Penelitian Geologi Kelautan (PPGL) di Bandung. Bahan-bahan baku lainnya mencakup $\mathrm{NaOH}$ yang berbentuk serpihan padat serta natrium silikat $\left(\mathrm{Na}_{2} \mathrm{SiO}_{3}\right)$ hidrat. Kedua bahan ini dibeli dalam kualitas teknis dari pemasok bahan-bahan kimia lokal di Bandung.

Alur sintesis yang dipaparkan oleh Liu dkk. (2006) diambil sebagai acuan metode pembuatan penyangga katalis FCC. Konsep utama dalam metode ini adalah pencampuran dua macam kaolin yang berbeda temperatur kalsinasinya sebagai umpan dalam penumbuhan fasa zeolit secara in-situ, dengan harapan bahwa kehadiran kaolin yang terkalsinasi pada temperatur relatif tinggi dapat meningkatkan kekuatan mekanik dari produk katalis. Langkah-langkah pembuatan katalis zeolit secara in-situ yang didasarkan pada alur dari Liu dkk. (2006) adalah sebagai berikut:

1. Kaolin mentah mula-mula disuspensikan dalam air dan diolah menjadi mikrosfer kaolin dengan proses pengeringan sembur. Mikrosfer kaolin merupakan partikel kaolin dengan geometri bola yang berdiameter beberapa puluh hingga beberapa ratus mikrometer.

2. Mikrosfer kaolin selanjutnya dipilah menjadi dua bagian. Satu bagian dikalsinasi pada temperatur rendah (antara 700-850 ${ }^{\circ} \mathrm{C}$ ), sementara sisanya dikalsinasi pada temperatur yang lebih tinggi, yakni $1000{ }^{\circ} \mathrm{C}$. Menurut paparan Liu dkk. (2006), kalsinasi rendah mengubah kaolin mentah menjadi metakaolin, sementara kalsinasi tinggi menghasilkan kaolin terkalsinasi penuh (dalam tulisan ini diistilahkan secara lebih singkat dengan kaolin terkalsinasi).

3. Kedua macam produk kalsinasi di atas selanjutnya dicampur dengan $\mathrm{Na}_{2} \mathrm{SiO}_{3}$ cair dan larutan $\mathrm{NaOH}$, dan direaksikan secara hidrotermal di dalam autoklaf.

Suatu percobaan dengan rancangan faktorial penuh $2^{3}$ (notasi untuk 3 variabel percobaan yang divariasikan pada 2 nilai / tingkat) tanpa replikasi $(n=1)$ dilaksanakan untuk mengukur pengaruh variabel temperatur kalsinasi rendah untuk sintesis metakaolin, waktu kalsinasi rendah, serta waktu reaksi hidrotermal atau zeolitisasi. Pengaturan variabel-variabel sintesis sesuai rancangan faktorial penuh $2^{3}$ ini diringkaskan dalam Tabel 1. Nilai minimum dari variabelvariabel percobaan didasarkan pada kajian Liu dkk. (2006). Nilai maksimum temperatur kalsinasi rendah didasarkan pada kajian terdahulu yang melibatkan konversi kaolin Belitung yang sama menjadi metakaolin (Samadhi dkk., 2011), sementara nilai maksimum waktu kalsinasi rendah dan waktu reaksi hidrotermal ditetapkan untuk menjamin diperolehnya efek yang relatif besar sehingga mudah diamati.

Pemilihan rancangan faktorial penuh ini didasarkan pada pertimbangan bahwa kajian ini masih bersifat awal, dimana pengaruh variabel-variabel sintesis terhadap karakteristik produk masih sama sekali belum diketahui sehingga belum diperlukan rancangan percobaan yang mampu menyusun model matematik yang canggih. Praduga bahwa tidak semua variabel akan berpengaruh terhadap hasil percobaan menjadi justifikasi untuk menjalankan percobaan tanpa replikasi tempuhan, demi penghematan biaya karakterisasi produk (Montgomery, 2009).

Untuk semua tempuhan, kalsinasi temperatur tinggi untuk pembuatan kaolin terkalsinasi dilaksanakan pada $1000{ }^{\circ} \mathrm{C}$ selama 2 jam dalam tanur listrik. Larutan $\mathrm{NaOH}$ yang digunakan sebagai pereaksi dalam proses hidrotermal diperoleh dengan melarutkan $\mathrm{NaOH}$ padat dengan air demineralisasi, pada konsentrasi $50 \%-\mathrm{w} / \mathrm{v}$. Reaksi hidrotermal dilangsungkan dalam autoklaf pada temperatur yang berkisar pada 90-100 ${ }^{\circ} \mathrm{C}$ (tidak dikendalikan), pada tekanan autogenik dengan waktu yang divariasikan pada 18 dan 24 jam. Produk reaksi hidrotermal kemudian disaring untuk memisahkannya dari sisa larutan alkali, dicuci dengan air bebas mineral, dan dikeringkan sebelum dikarakterisasi.

Tabel 1. Pengaturan Variabel-Variabel Percobaan

\begin{tabular}{lcc}
\hline \multicolumn{1}{c}{ Variabel } & Nilai rendah $(-)$ & Nilai tinggi $(+)$ \\
\hline Temperatur kalsinasi rendah $\left(\mathrm{x}_{1}\right)$ & $700{ }^{\circ} \mathrm{C}$ & $850{ }^{\circ} \mathrm{C}$ \\
Waktu kalsinasi rendah $\left(\mathrm{x}_{2}\right)$ & $2 \mathrm{jam}$ & $24 \mathrm{jam}$ \\
Waktu reaksi hidrotermal $\left(\mathrm{x}_{3}\right)$ & $18 \mathrm{jam}$ & 24 jam \\
\hline
\end{tabular}


Karakterisasi produk dalam kajian ini ditujukan untuk mengetahui efektivitas alur sintesis dalam mengkonversi secara parsial mikrosfer kaolin menjadi zeolit Y (atau faujasit), dan secara spesifik mencakup butirbutir uji sebagai berikut:

- karakterisasi fasa menggunakan difraksi sinar-X terhadap bahan baku kaolin dan produk antara metakaolin, untuk memverifikasi secara kualitatif kesesuaian rentang temperatur kalsinasi yang dipilih

- karakterisasi fasa terhadap produk akhir yang diperoleh pada percobaan faktorial $2^{3}$ di atas, juga menggunakan teknik difraksi sinar-X

- pengukuran luas permukaan spesifik, volume pori, serta ukuran median pori produk akhir dengan menggunakan metode adsorpsi gas nitrogen dengan isoterm BET (Brunauer-Emmett-Teller)

Pembentukan mikrosfer kaolin dilakukan dengan unit pengering sembur berskala lab tipe Eyela SD-01 di Laboratorium Teknologi Fermentasi Pusat Antar Universitas ITB (PAU-ITB). Karakterisasi dengan difraksi sinar-X dilaksanakan di fasilitas laboratorium PPGL di Bandung menggunakan unit difraktometer sinar-X (XRD) Phillips PW 1835 dengan sumber radiasi $\mathrm{CuK} \alpha$ (dengan panjang gelombang 1,54 ̊̊), sementara karakterisasi adsorpsi nitrogen dilaksanakan dengan instrumen Quantachrome Nova 1000 di Program Studi Teknik Kimia ITB. Disamping uji-uji di atas, dilaksanakan pula karakterisasi morfologi dan geometri partikel dengan mikroskop elektron pindaian (SEM) tipe JEOL JSM-6360LA di fasilitas laboratorium Basic Science FMIPA-ITB.

\section{HASIL DAN PEMBAHASAN}

Karakterisasi Bahan Baku Kaolin Belitung Difraktogram bahan kaolin Belitung mentah ditampilkan dalam Gambar 1 . Berdasarkan sebaran sudut difraksi serta intensitas relatif puncak-puncak difraksi yang diperoleh, fasa kaolinit, gibsit, dan kuarsa teridentifikasi sebagai komponen-komponen mineral utama. Meski tidak dilakukan kuantifikasi, tinggi relatif puncak-puncak difraksi mengisyaratkan bahwa kandungan fasa gibsit dan kuarsa jauh lebih rendah daripada kaolinit. Secara umum, sebaran kualitatif fasa-fasa ini sesuai dengan karakteristik umum mineral kaolin (Sebagai contoh, simak paparan karakterisasi mineral kaolin oleh Haq dkk. (2009) dan Sunardi (2010)).

Analisis komposisi oksida kaolin Belitung dicantumkan dalam Tabel 2. Tabel ini menunjukkan bahwa rumus kimia empirik mineral kaolin Belitung ini adalah $\mathrm{Si}_{2,11} \mathrm{Al}_{1,87} \mathrm{O}_{3,98}$, dengan nisbah $\mathrm{Si} / \mathrm{Al}$ 1,2:1. Nilai nisbah Si/Al ini mendekati rumus teoritik untuk kaolin, yaitu $\mathrm{Al}_{2} \mathrm{O}_{3} \cdot 2 \mathrm{SiO}_{2} \cdot 2 \mathrm{H}_{2} \mathrm{O}$. Fasa-fasa oksida pengotor dalam sampel ini mencakup $\mathrm{CaO}, \mathrm{Na}_{2} \mathrm{O}, \mathrm{K}_{2} \mathrm{O}, \mathrm{Fe}_{2} \mathrm{O}_{3}, \mathrm{TiO}_{2}$, serta MgO, yang terdeteksi pada kadar yang sebanding satu sama lain, yakni di bawah 1,0\%-massa.

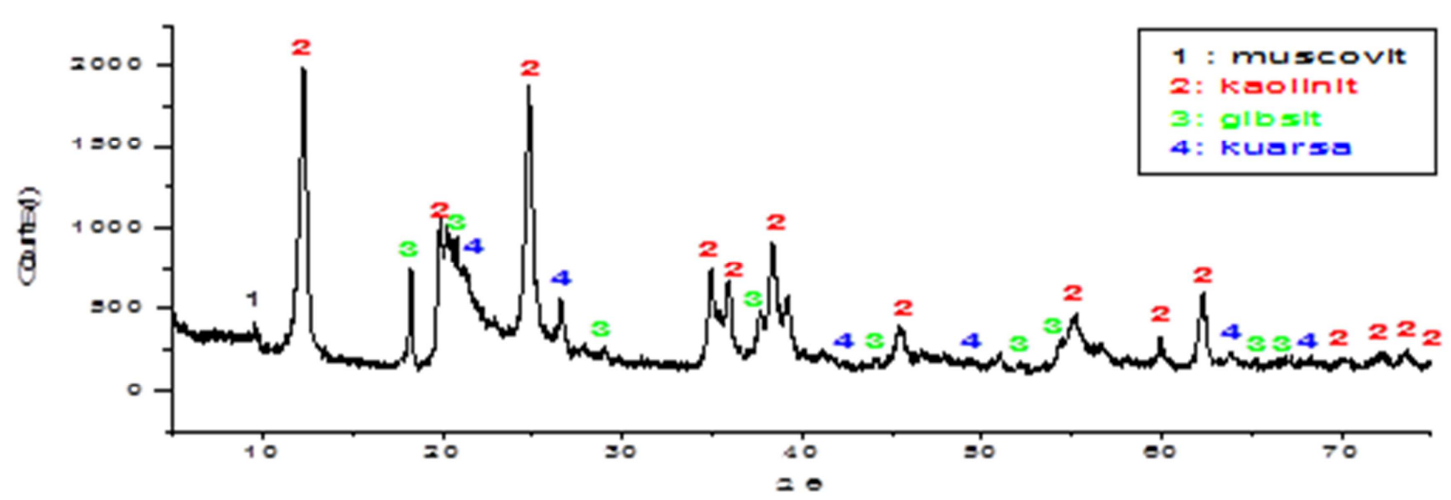

Gambar 1: Difraktogram sinar X bahan baku kaolin Belitung

Tabel 2. Komposisi Oksida Kaolin Belitung dalam \%-Massa

\begin{tabular}{cccccccccc}
\hline Sampel & $\% \mathrm{SiO}_{2}$ & \% $_{2} \mathrm{Ol}_{3}$ & $\mathbf{\% F e}_{2} \mathrm{O}_{3}$ & $\mathbf{\% T i O}_{2}$ & $\% \mathrm{CaO}$ & $\% \mathrm{MgO}$ & $\% \mathrm{Na}_{2} \mathrm{O}$ & $\% \mathrm{~K}_{2} \mathrm{O}$ & $\begin{array}{c}\text { Hilang } \\
\text { Pijar }\end{array}$ \\
\hline Kaolin & 46,77 & 38,17 & 0,37 & 0,22 & 0,64 & 0,14 & 0,12 & 0,1 & 13,47 \\
\hline
\end{tabular}


Morfologi partikel kaolin mentah ditampilkan dalam mikrograf SEM pada Gambar 2. Mikrostruktur kaolin Belitung didominasi oleh partikel-partikel lembaran heksagonal dengan ukuran sekitar $1 \mu \mathrm{m}$. Seperti yang dipaparkan oleh Murray (2007), morfologi lembaran heksagonal tertumpuk ini merupakan salah satu ciri khas mineral kaolinit.

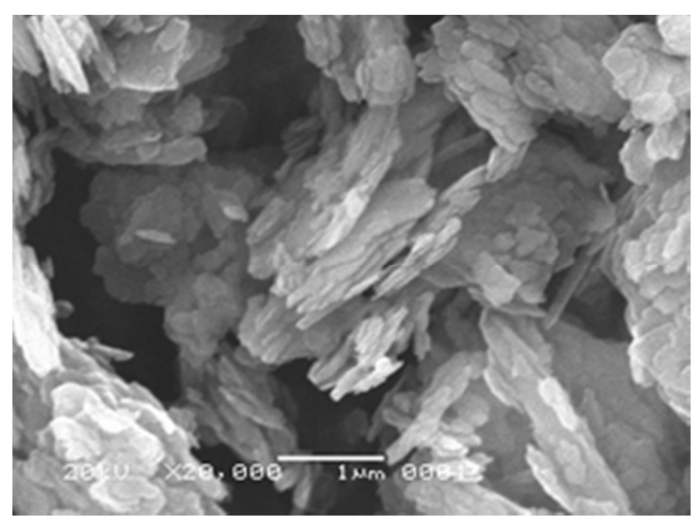

Gambar 2. Mikrograf SEM sample kaolin Belitung pada perbesaran $20.000 \times$

\section{Pembuatan dan Karakterisasi Mikrosfer} Kaolin

Penyiapan mikrosfer kaolin diawali dengan pencampuran kaolin mentah dengan air dan natrium silikat, pada kadar kaolin 10 $\%$-massa. Natrium silikat ditambahkan pada kadar $5 \%$-massa relatif terhadap massa total cairan sebagai zat pengikat. Unit pengering sembur yang digunakan untuk membuat mikrosfer kaolin dioperasikan pada laju alir suspensi sekitar $6 \mathrm{~mL} /$ menit dan temperatur udara keluaran sekitar $110{ }^{\circ} \mathrm{C}$. Mikrosfer kering yang diperoleh didinginkan di dalam eksikator sebelum disimpan dalam wadah kedap udara. Mikrosfer kaolin ini selanjutnya dipilah menjadi dua bagian. Sebagian dikalsinasi menjadi metakaolin pada temperatur bervariasi sesuai dengan rancangan percobaan utama dalam Tabel 1 , dan sisanya dikalsinasi pada $1000^{\circ} \mathrm{C}$.

Difraktogram sinar-X dari mikrosfer metakaolin yang dikalsinasi pada temperatur $850{ }^{\circ} \mathrm{C}$ selama 24 jam ditampilkan dalam Gambar 3. Perbandingan dengan Gambar 2 jelas menunjukkan derajat kristalinitas metakaolin yang jauh lebih rendah daripada kaolin, yang diisyaratkan dengan hilang dan/atau menumpulnya puncak-puncak difraksi yang semula teramati dengan jelas pada difraktogram kaolin mentah. Proses dehidroksilasi yang berlangsung selama kalsinasi menyebabkan deteriorasi struktur kristal kaolin, sehingga secara sepintas metakaolin menunjukkan karakteristik menyerupai bahan amorf dalam difraksi sinar-X. Pengamatan ini juga menunjukkan bahwa rentang temperatur kalsinasi yang dipilih dalam rancangan percobaan utama, yakni $700-850{ }^{\circ} \mathrm{C}$, sudah memadai untuk mengubah kaolin Belitung menjadi metakaolin.

Mikrograf SEM permukaan mikrosfer metakaolin ditampilkan dalam Gambar 4 . Sebagai pembanding, mikrograf bahan metakaolin curah yang diperoleh oleh kelompok peneliti penulis dan telah dipublikasikan sebelumnya (Samadhi dkk., 2011) juga ditampilkan dalam Gambar 4.

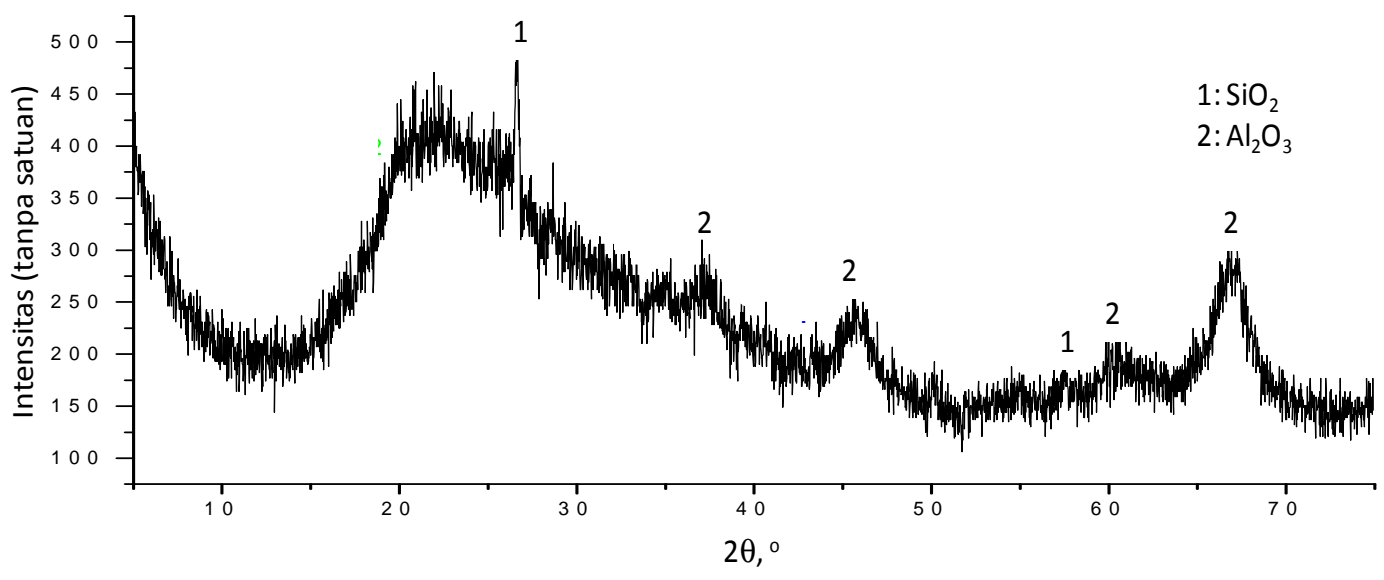

Gambar 3. Difraktogram sinar -X mikrosfer metakaolin kalsinasi $850^{\circ} \mathrm{C}$ selama 24 jam 

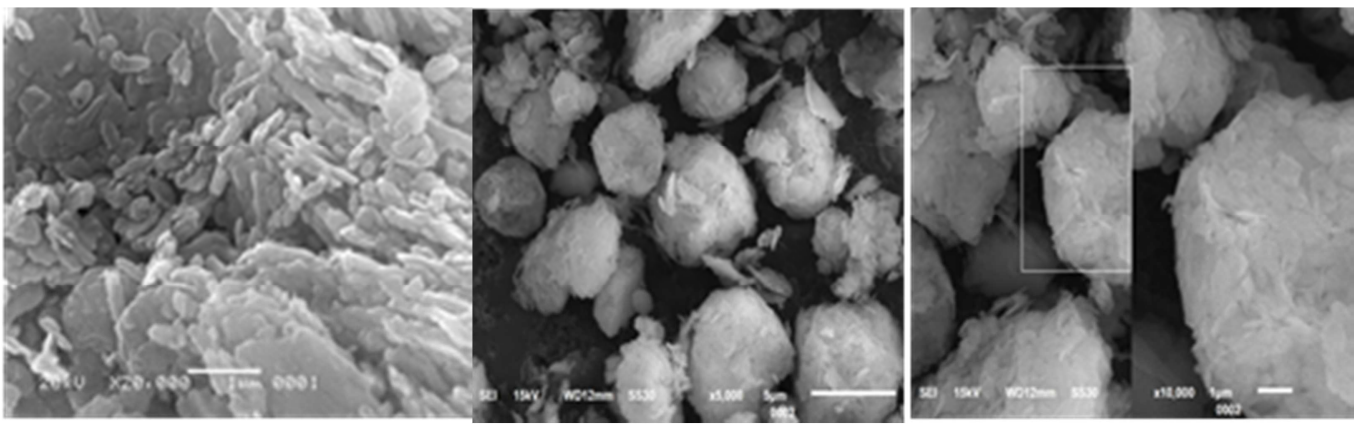

Gambar 4. (a) morfologi permukaan metakaolin (Samadhi dkk., 2011), (b) morfologi permukaan mikrosfer metakaolin perbesaran 5000x, (c) morfologi mikrosfer metakaolin perbesaran 10.000x

Perbandingan antara Gambar 4.a. dengan Gambar 2 menunjukkan perubahan morfologi bahan yang terjadi karena proses kalsinasi. Hilangnya gugus-gugus hidroksil yang semula menjadi jembatan antara lembaran-lembaran aluminosilikat dalam struktur kristal menyebabkan terjadinya delaminasi atau terurainya lembaranlembaran aluminosilikat dalam struktur kaolin semula. Gambar 4.b. menunjukkan geometri bola yang umum ditunjukkan oleh bahan partikulat yang dibentuk melalui proses pengeringan sembur. Dibandingkan dengan mikrosfer kaolin yang dipaparkan dalam literatur (Basaldella dkk., 1993 dan Liu dkk., 2006), nampak bahwa geometri produk yang dihasilkan dalam penelitian ini masih terdistorsi, baik dalam hal bentuk yang tidak betul-betul membola, maupun dalam hal cukup banyaknya mikrosfer yang pecah menjadi partikel-partikel yang lebih kecil dan tidak berbentuk bola. Kajian lain yang dilaksanakan penulis utama (Samadhi dkk., 2012) tentang pengaruh variabel-variabel operasi pengeringan sembur mengisyaratkan bahwa distorsi mikrosfer ini disebabkan oleh laju umpan suspensi yang terlalu tinggi, yang menimbulkan gaya geser berlebihan terhadap tetesan suspensi pada saat melewati nosel pengering.

\section{Sintesis dan Karakterisasi Mikrosfer Zeolit}

Formulasi bahan-bahan baku untuk sintesis zeolit secara in-situ, yakni mikrosfer metakaolin, mikrosfer kaolin terkalsinasi penuh, serta natrium silikat, diatur untuk mencapai target komposisi molar oksida $9 \mathrm{Na}_{2} \mathrm{O} \cdot \mathrm{Al}_{2} \mathrm{O}_{3} \cdot 10 \mathrm{SiO}_{2} \cdot 193 \mathrm{H}_{2} \mathrm{O}$. Dengan menggunakan bahan-bahan yang diperoleh dari tahap-tahap pekerjaan sebelumnya, diperoleh angka-angka nisbah komposisi yang diringkaskan dalam Tabel 3.
Tabel 3. Perbandingan Rasio Molar Oksida Sintesis Faujasit

\begin{tabular}{lllll}
\hline & $\begin{array}{l}\mathrm{SiO}_{2} / \\
\mathrm{Al}_{2} \mathrm{O}_{3}\end{array}$ & $\begin{array}{l}\mathrm{Na}_{2} \mathrm{O} / \\
\mathrm{SiO}_{2}\end{array}$ & $\begin{array}{l}\mathrm{H}_{2} \mathrm{O} / \\
\mathrm{Na}_{2} \mathrm{O}\end{array}$ & $\begin{array}{l}\mathrm{H}_{2} \mathrm{O} / \\
\text { mikro } \\
\text { sfer }\end{array}$ \\
\hline $\begin{array}{l}\text { Literatur } \\
\text { (tanley } \\
\text { dkk., 1985) }\end{array}$ & $5-13$ & $0,3-0,6$ & $20-35$ & $4-12$ \\
Penelitian & 10 & 0,9 & 21,4 & 12,1 \\
\hline
\end{tabular}

Nisbah molar $\mathrm{SiO}_{2} / \mathrm{Al}_{2} \mathrm{O}_{3}$ merupakan salah satu parameter yang penting dalam sintesis zeolit, karena akan menentukan jenis zeolit yang akan dihasilkan dan bentuk rongga dari zeolit tersebut (Stanley dkk., 1985). Keberadaan natrium dalam sintesis zeolit juga perlu diperhatikan. Dalam sintesis zeolit, logam alkali ( $\mathrm{Na}$ ) akan bereaksi dan berikatan dengan Si-O dan Al-O pada rangka zeolit dan berfungsi sebagai penyedia pusat aktif. Keberadaan air pada proses kristalisasi zeolit mempunyai peranan sebagai pelarut dan sebagai pembentuk kerangka zeolit. Dalam proses kristalisasi zeolit, nisbah molar $\mathrm{H}_{2} \mathrm{O} / \mathrm{Na}_{2} \mathrm{O}$ berada pada rentang 20-35. Reaksi yang berlangsung pada nisbah lebih rendah dapat menyebabkan mikrosfer tidak beraksi secara sempurna dan proses pembentukan zeolit berlangsung sangat lambat (Stanley dkk., 1985).

Gambar 5 menunjukkan difraktogram dari sampel mikrosfer zeolit yang diproses melalui kalsinasi metakaolin pada temperatur $850{ }^{\circ} \mathrm{C}$ selama 24 jam, diikuti reaksi hidrotermal pada temperatur $100{ }^{\circ} \mathrm{C}$ selama 24 jam. Identifikasi fasa yang terbentuk pada produk akhir dilakukan dengan membandingkan pola difraksi produk dengan pola difraksi standar zeolit $\mathrm{NaY}$ yang memiliki struktur kristal faujasit (ASTM D3906-03), seperti yang diringkaskan dalam Tabel 4. Puncak-puncak difraksi fasa faujasit dalam 


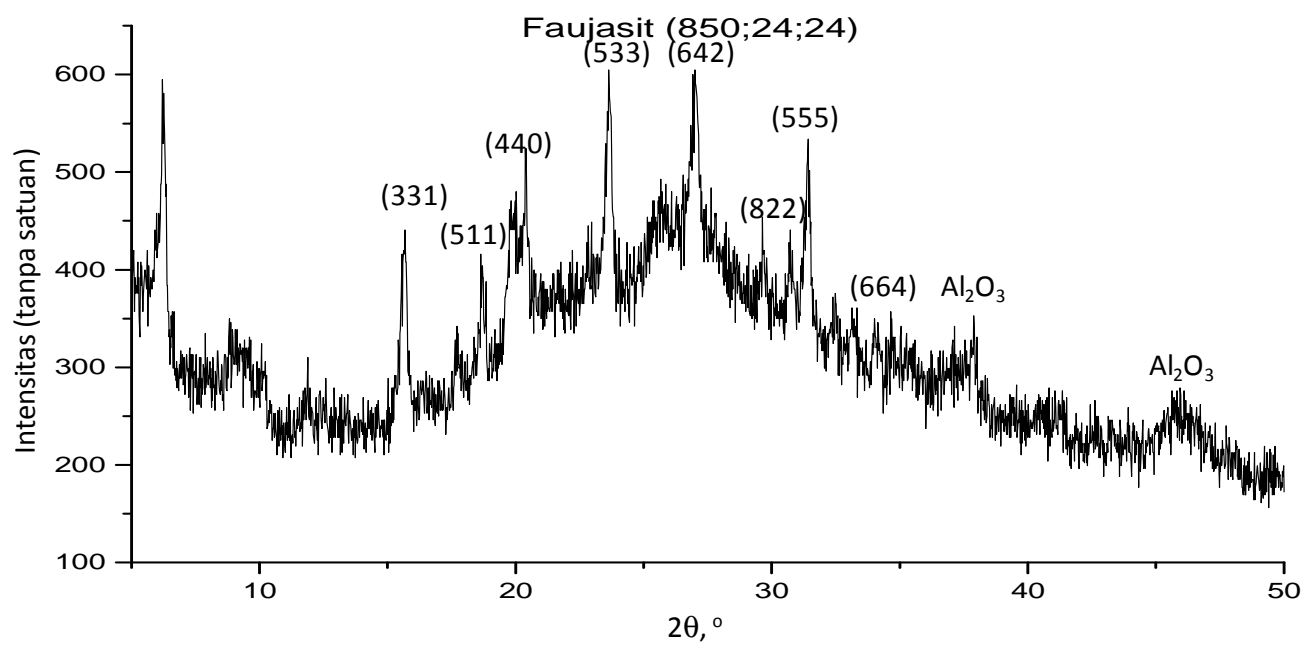

Gambar 5. Difraktogram sinar-X faujasit sintesis yang dikalsinasi pada $850{ }^{\circ} \mathrm{C}, 24$ jam dan kristalisasi 24 jam

Tabel 4. Identifikasi Puncak-Puncak Difraksi Faujasit Menggunakan Standar ASTM D390603

\begin{tabular}{cccccc}
\hline & & \multicolumn{2}{c}{ Sudut difraksi dengan radiasi } & \multirow{2}{*}{ Jarak antar bidang kristal $\left(\mathrm{d}_{\mathrm{hkl}}, \AA\right)$} \\
\cline { 3 - 6 } No. & $\begin{array}{c}\text { Indeks Miller } \\
\text { (hkl) }\end{array}$ & $\begin{array}{c}\text { ASTM D3906- } \\
03\end{array}$ & Sampel & ASTM D3906-03 & Sampel \\
\hline 1 & & $15.7 \pm 0.2$ & 15.7 & 5.64 & 5.64 \\
2 & 531 & $18.7 \pm 0.2$ & 19.2 & 4.74 & 4.62 \\
3 & 41,333 & $20.4 \pm 0.3$ & 20.5 & 4.35 & 4.33 \\
4 & 533 & $23.7 \pm 0.4$ & 23.7 & 3.75 & 3.75 \\
5 & 642 & $27.1 \pm 0.5$ & 27.0 & 3.29 & 3.30 \\
6 & 822,660 & $30.8 \pm 0.5$ & 30.7 & 2.90 & 2.91 \\
7 & 555,751 & $31.5 \pm 0.5$ & 31.3 & 2.84 & 2.85 \\
8 & 664 & $34.2 \pm 0.6$ & 33.9 & 2.62 & 2.64 \\
\hline
\end{tabular}

Gambar 5 ditandai dengan indeks Miller masing-masing puncak.

Sudut-sudut difraksi serta nilai-nilai jarak antar bidang kristal $\left(\mathrm{d}_{\mathrm{hkl}}\right)$ yang dihitung berdasarkan sudut-sudut difraksi menunjukkan bahwa pola difraksi fasa yang terbentuk setelah reaksi hidrotermal konsisten dengan fasa faujasit menurut standar ASTM D3906-03. Meski demikian, difraktogram mikrosfer zeolit yang diperoleh (Gambar 5) masih menunjukkan intensitas derau yang masih cukup tinggi, yang mengisyaratkan bahwa reaksi kristalisasi faujasit pada permukaan mikrosfer kaolin belum tuntas ketika proses dihentikan. Hal ini juga diisyaratkan oleh teramatinya puncakpuncak $\mathrm{Al}_{2} \mathrm{O}_{3}$ pada Gambar 5 .

Gambar 6.a dan 6.b menampilkan hasil karakterisasi morfologi permukaan mikrosfer yang telah melalui proses hidrotermal untuk mengkonversi kaolin menjadi zeolit. Secara lebih khusus, Gambar 6.b menunjukkan pertumbuhan butir-butir kristal berukuran kecil dengan perbandingan panjang dan lebar yang lebih mendekati geometri kubus ketimbang jarum. Morfologi seperti ini merupakan ciri khas dari proses kristalisasi fasa zeolit pada permukaan kaolin, konsisten dengan pengamatan yang dipaparkan oleh Basaldella dkk. (1993) dan San Cristóbal dkk. (2010). Pengamatan ini memperkuat hasil karakterisasi difraksi sinar-X, yang mengindikasikan bahwa proses reaksi hidrotermal terhadap mikrosfer metakaolin berhasil menumbuhkan fasa faujasit pada permukaan mikrosfer. Pertumbuhan fasa faujasit masih belum menutup seluruh permukaan mikrosfer. Hal ini ditunjukkan oleh butir-butir berukuran besar yang masih nampak dengan jelas pada permukaan sampel mikrosfer. Butir-butir ini diduga merupakan sisa metakaolin atau silika bebas yang masih belum bereaksi dalam proses hidrotermal. Penambahan waktu reaksi hidrotermal dinilai 
merupakan cara yang efektif untuk menuntaskan reaksi pembentukan faujasit pada permukaan mikrosfer metakaolin.

Tabel 5 menampilkan data hasil karakterisasi tekstural sampel dengan metode adsorpsi nitrogen pada permukaan mikrosfer setelah reaksi hidrotermal, yang dinyatakan dalam 3 besaran karakteristik, yakni luas permukaan spesifik, median diameter pori, serta volume pori. Pengolahan data secara statistik dilaksanakan terhadap luas permukaan spesifik, yang dianggap sebagai besaran karakteristik terpenting dalam fungsi mikrosfer sebagai katalis FCC.

Karakteristik tekstural dari mikrosfer setelah zeolitisasi in-situ berbeda cukup jauh dengan hasil-hasil yang dipaparkan oleh Liu dkk. (2006). Para peneliti ini melaporkan luas permukaan spesifik sebesar 425,3 $\mathrm{m}^{2} / \mathrm{g}$, volume pori $0,368 \mathrm{~cm}^{3} / \mathrm{g}$, serta diameter pori rata-rata $34,8 \AA$ A. Sebagai perbandingan, katalis FCC yang dibuat dengan metode inkorporasi zeolit US-Y (ultra stable Y) dengan matriks silika-alumina amorf oleh Al-Khattaf (2002) memiliki luas permukaan spesifik 125$201 \mathrm{~m}^{2} / \mathrm{g}$. Katalis serupa yang dibuat oleh Tonetto dkk. (2004) dengan menggunakan kaolin sebagai bahan pengisi menghasilkan luas permukaan spesifik $169-213 \mathrm{~m}^{2} / \mathrm{g}$, pori volume total $0,13-0,15 \mathrm{~cm}^{3} / \mathrm{g}$, serta median diameter pori berkisar pada 10-11 $\AA$, yang merupakan nilai tipikal untuk fasa zeolit-Y / faujasit. Masih rendahnya luas permukaan spesifik serta volume pori yang diperoleh dalam kajian ini mengisyaratkan perlunya kajian yang lebih mendalam untuk mengidentifikasi variabel-variabel kunci dalam reaksi hidrotermal, sehingga dapat ditemukan kondisi proses terbaik untuk bahan baku kaolin Belitung ini.

Hasil pengolahan statistik terhadap data luas permukaan spesifik dalam Tabel 5 dengan metode ANOVA diringkaskan dalam Tabel 6. Analisis dilakukan menggunakan nilai-nilai variabel percobaan yang terkodekan (coded variables), yakni variabel yang telah ditransformasikan sehingga nilainya bervariasi pada rentang -1 hingga +1 . Signifikansi atau keberartian masing-masing komponen efek dinyatakan dengan nilai probabilitas (nilai-P) kesalahan uji hipotesis terhadap setiap efek tersebut. Angka-angka nilai-P di Tabel 6 menunjukkan tingkat keberartian yang kurang baik, kecuali untuk

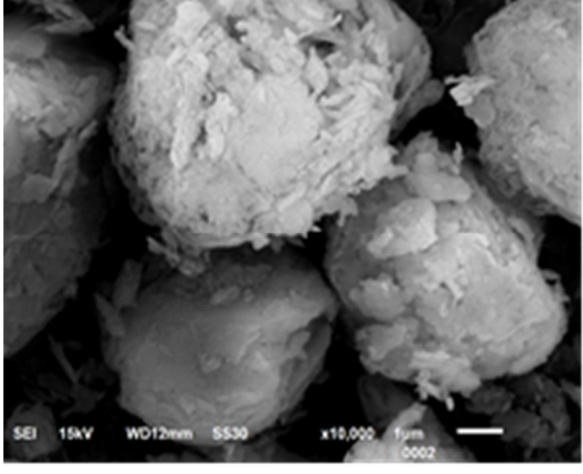

a

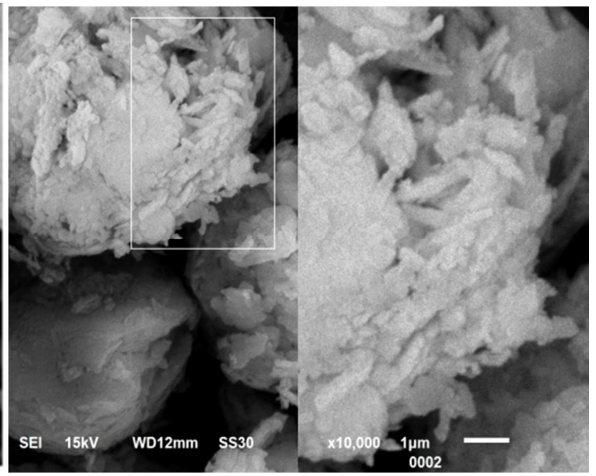

$\mathrm{b}$

Gambar 6. Hasil SEM faujasite (a) perbesaran 5000x, (b) perbesaran $10.000 \times$

Tabel 5. Rangkuman Hasil Karakterisasi Sampel Mikrosfer dengan Metode Adorpsi Nitrogen

\begin{tabular}{ccccccc} 
Tempuhan & $\begin{array}{c}\text { T kalsinasi } \\
\text { rendah } \\
\left({ }^{\circ} \mathrm{C}\right)\end{array}$ & $\begin{array}{c}\text { t kalsinasi } \\
\text { rendah } \\
\text { (jam) }\end{array}$ & $\begin{array}{c}\mathrm{t} \\
\text { kristalisasi } \\
\text { (jam) }\end{array}$ & $\begin{array}{c}\text { Radius } \\
\text { Pori }(\AA)\end{array}$ & $\begin{array}{c}\text { SSA } \\
\left(\mathrm{m}^{2} / \mathrm{g}\right)\end{array}$ & $\begin{array}{c}\text { Vtot pori } \\
\left(\mathrm{cm}^{3} / \mathrm{g}\right)\end{array}$ \\
\hline 1 & 850 & 2 & 18 & 13,8 & 90 & 0,062 \\
2 & 700 & 2 & 18 & 13,5 & 117,5 & 0,080 \\
3 & 850 & 24 & 18 & 13,3 & 24 & 0,017 \\
4 & 700 & 24 & 18 & 13,6 & 142,1 & 0,097 \\
5 & 850 & 2 & 24 & 13,5 & 111,8 & 0,076 \\
6 & 700 & 2 & 24 & 13,8 & 87,8 & 0,060 \\
7 & 850 & 24 & 24 & 15,6 & 57,9 & 0,039 \\
8 & 700 & 24 & 24 & 13,1 & 10,5 & 0,007 \\
\hline
\end{tabular}


komponen interaksi $\mathrm{X}_{1} \mathrm{X}_{3}$, atau interaksi antara temperatur kalsinasi dengan periode waktu kristalisasi/reaksi hidrotermal. Diantara efek-efek utama atau efek-efek individual variabel percobaan, waktu kalsinasi $\left(\mathrm{X}_{2}\right)$ justru menunjukkan tingkat signifikansi yang paling tinggi, meskipun inipun tidak dapat disimpulkan dengan tingkat keyakinan yang tinggi karena nilai-P efek tersebut masih lebih besar daripada nilai 0,10 yang banyak dijadikan patokan bagi analisis data yang mengandung ketidakpastian relatif besar.

Dengan demikian, hasil pengolahan data dengan metode ANOVA ini mengidentifikasi efek utama waktu kalsinasi metakaolin dan interaksi antara temperatur kalsinasi metakaolin dan waktu kristalisasi sebagai faktor-faktor penentu luas permukaan spesifik mikrosfer faujasit. Berdasarkan tanda negatif/positif koefisien tiap komponen efek ini, dapat disimpulkan pula bahwa dalam rentang variabel-variabel percobaan yang diuji, luas permukaan spesifik dapat ditingkatkan dengan menggunakan waktu kalsinasi metakaolin yang relatif pendek, dan temperatur kalsinasi metakaolin serta waktu reaksi hidrotermal yang keduanya diatur secara serempak pada level tinggi.

\section{Tabel 6. Rangkuman Hasil Pengolahan Data Luas Permukaan Spesifik dengan Metode ANOVA}

\begin{tabular}{lccc}
\hline $\begin{array}{c}\text { Komponen } \\
\text { efek }\end{array}$ & Efek & Koefisien & $\begin{array}{c}\text { Nilai- } \\
\mathrm{P}\end{array}$ \\
\hline T kalsinasi $\left(\mathrm{X}_{1}\right)$ & $-18,55$ & $-9,27$ & 0,480 \\
t kalsinasi $\left(\mathrm{X}_{2}\right)$ & $-43,15$ & $-21,57$ & 0,158 \\
t kristalisasi $\left(\mathrm{X}_{3}\right)$ & $-26,40$ & $-13,20$ & 0,336 \\
interaksi $\mathrm{X}_{1} \cdot \mathrm{X}_{3}$ & 54,25 & 27,13 & 0,100 \\
\hline
\end{tabular}

\section{KESIMPULAN}

Kajian awal ini telah berhasil membuktikan sejumlah aspek kelayakan teknis pengolahan kaolin Belitung menjadi katalis FCC melalui proses zeolitisasi secara in-situ. Proses diawali dengan penyiapan mikrosfer kaolin dengan proses pengeringan sembur. Selanjutnya, kaolin dikalsinasi pada 2 tingkat temperatur, yakni menengah (700$\left.850{ }^{\circ} \mathrm{C}\right)$ dan tinggi $\left(1000{ }^{\circ} \mathrm{C}\right)$. Rentang temperatur menengah ini terbukti cukup untuk mengubah kaolin menjadi metakaolin yang bersifat semi-amorf melalui proses dehidroksilasi. Penumbuhan kristal zeolit-Y atau faujasit pada permukaan mikrosfer dilakukan melalui reaksi hidrotermal dengan larutan $\mathrm{NaOH}$ pada temperatur $100-110^{\circ} \mathrm{C}$.
Dalam periode waktu reaksi 18-24 jam, analisis fasa dengan difraksi sinar-X membuktikan terbentuknya faujasit. Karakterisasi morfologi produk akhir menunjukkan distorsi geometri mikrosfer serta kerusakan partikel, yang mengisyaratkan pentingnya menjaga laju umpan suspensi dalam proses pengeringan sembur supaya tidak berlebihan. Pertumbuhan kristal faujasit berhasil diidentifikasi secara visual dengan pencitraan SEM, yang nampak sebagai butir-butir berukuran kecil dengan kelakuan pertumbuhan kristal kubik. Luas permukaan spesifik dan volume pori total produk masih lebih rendah daripada hasil-hasil yang dipaparkan di literatur. Hal ini menunjukkan perlunya dilaksanakan kajian lebih mendalam mengenai pengaruh variabel-variabel proses hidrotermal/zeolitisasi in-situ, untuk mencari kondisi operasi yang sesuai dengan bahan baku kaolin Belitung ini. Analisis statistik terhadap data luas permukaan spesifik mengidentifikasi waktu kalsinasi serta interaksi antara temperatur kalsinasi dan waktu reaksi hidrotermal sebagai faktorfaktor yang berpengaruh secara berarti.

\section{DAFTAR PUSTAKA}

Al-Khattaf, S., The influence of y-zeolite unit cell size on the performance of FCC catalysts during gas oil catalytic cracking, Applied Catalysis A: General, 2002, 231, 293-306.

Basaldella, E. I.; Bonetto, R.; Tara, J. C., Synthesis of NaY zeolite on preformed kaolinite spheres: evolution of zeolite content and textural properties with the reaction time, Industrial and Engineering Chemistry Research, 1993, 32(4), 751-752.

Brown, S. M.; Durante, V. A.; Reagan, W. J.; Speronello, B. K., Fluid Catalytic Cracking Catalyst Comprising Microspheres Containing more than About 40 Percent by Weight $Y$ Faujasite and Methods for Making, U.S. Patent 4,493,902, 15 Januari 1985.

Haq, A.; Iqbal, Y.; Khan, M. R., Phase and microstructural characterization of kaolin clays from north western pakistan, Journal of Pakistani Materials Society, 2009, 3(2), 77-90.

Liu, H.; Ma, J.; Gao, X., Synthesis, characterization and evaluation of a novel resid FCC catalyst based on in-situ synthesis 
on kaolin microspheres, Catalysis Letters, 2006, 110(3-4), 229-234.

Montgomery, D. C., Design and Analysis of Experiments; $7^{\text {th }}$ Eds., John Wiley \& Sons: New York, 2009; hlm. 229-234.

Murray, H. H., Applied Clay Mineralogy: Occurences, Processing and Application of Kaolins, Bentonites, Palygorskite-Sepiolite, and Common Clays; First Edition, Elsevier: Amsterdam, The Netherlands, 2007.

Sadeghbeigi, R., Fluid Catalytic Cracking Handbook: Design, Operation, \& Troubleshooting of FCC Facilities; $2^{\text {nd }}$ Eds., Gulf Professional Publishing: Houston, USA, 2000; hlm. 1-6 \& 84-90.

Samadhi, T. W.; Subagjo.; Lismana, K. R.; Fuadi, $\mathrm{K}$., Synthesis of $\gamma-\mathrm{Al}_{2} \mathrm{O}_{3}$ catalyst support from kaolin of Indonesian origin, ITB Journal of Engineering Science, 2011, 34(2), 113-126.

Samadhi, T. W.; Saribhawani, Y.; Nafiani, I., Pengembangan Kaolin Mikrosferoidal untuk
Penyangga Katalis Perengkahan, Prosiding Seminar Nasional Teknik Kimia Indonesia 2012, Depok, 20-21 September 2012

San Cristóbal, A. G.; Castelló, R.; Martín Luengo, M. A.; Vizcayno, C., Zeolites prepared from calcined and mechanically modified kaolins: a comparative study, Applied Clay Science, 2010, 49(3), 239-246.

Sunardi, Kajian spektroskopi FTIR, XRD dan SEM kaolin alam asal tatakan, kalimantan selatan hasil purifikasi dengan metode sedimentasi, Sains dan Terapan Kimia, 2010, 4(2), 137-149.

Tonetto, G.; Atias, J.; de Lasa, H., FCC catalysts with different zeolite crystallite sizes: acidity, structural properties and reactivity, Applied Catalysis A: General, 2004, 270(1-2), 9-25.

Yilmaz, B.; Trukhan, N.; Muller, U., Industrial outlook on zeolites and metal organic frameworks, Chinese Journal of Catalysis, 2012, 33(1), 3-10. 